\title{
ОСОБЛИВОСТІ ФЕРМЕНТАТИВНОЇ ТА БІЛКОВОУТВОРЮВАЛЬНОЇ ФУНКЦИЙ ПЕЧІНКИ ЗА УМОВ ЕКСПЕРИМЕНТАЛЬНОГО ХРОНІЧНОГО ТОКСИЧНОГО ГЕПАТИТУ В СТАТЕВОЗРІЛИХ САМОК БІЛИХ ЩУРІВ ТА ЇХ ВПЛИВ НА РЕПРОДУКЦІЮ
}

Проблема порушень функції репродуктивної системи займає одне з провідних місць серед гінекологічних захворювань і продовжує бути актуальною, оскільки призводить до втрати працездатності та зниження репродуктивної функції. Значна роль у цьому належить не лише генетично детермінованим особливостям організму, але й супутній патології. у жінок часто спостерігають поєднання порушень функції репродуктивної системи з хронічними гепатитами різного генезу. Це спонукало нас до проведення експериментальної роботи з метою детального вивчення та аналізу вказаної проблеми. Було змодельовано хронічний токсичний гепатит у статевозрілих самок білих щурів. Вивчено результати клінічних, гістологічних досліджень, показники імунного та гормонального статусу, стан ферментативної і білковоутворювальної функцій печінки в піддослідних тварин, а також їх репродуктивну функцію за умов експериментального токсичного гепатиту. Обстежено 60 статевозрілих самок білих щурів, у яких змодельовано хронічний токсичний гепатит. Досліджено клінічні прояви захворювання, стан ферментативної та білковоутворювальної функцій печінки $i$ репродуктивну функцію цих тварин.

КЛЮЧОВІ СЛОВА: ферментативна та білковоутворювальна функції печінки, хронічний токсичний гепатит, репродуктивна функція.

ВСТУП. Порушення функції репродуктивної системи в жінок залишаються актуальною проблемою, незважаючи на вагомі наукові досягнення в її вивченні. Зростання захворюваності репродуктивної системи призводить не лише до втрати працездатності, але й до зниження репродуктивної функції. У жінок часто спостерігають поєднання порушень функції репродуктивної системи з хронічними гепатитами різного генезу $[3,5,8] .3$ метою більш детального вивчення та аналізу вказаної проблеми, виявлення змін, які мають вплив на патогенез захворювання, проведено експериментальне дослідження. Було змодельовано хронічний токсичний гепатит у статевозрілих самок білих щурів. Вивчено результати клінічних, біохімічних досліджень у піддослідних тварин, а також їх репродуктивну функцію за умов експериментального токсичного гепатиту. Обстежено 60 самок білих щурів репродуктивного віку, в яких змодельовано хронічний токсичний гепатит.

Метою даного дослідження було вивчити клінічні прояви захворювання, визначити показ(с) Л. Є. Лимар, 2015. ники імунної системи і стан репродуктивної функції піддослідних тварин за умов експериментального хронічного токсичного гепатиту [2, $4,6]$.

МЕТОДИ ДОСЛІДЖЕННЯ. Проведено експериментальну частину роботи. Змодельовано хронічний токсичний гепатит. Моделлю токсичного ураження тварин слугувала інтоксикація тетрахлорметаном $\left(\mathrm{CCl}_{4}\right)$. Тетрахлорметан вводили через день внутрішньошлунково у вигляді 50 \% олійного розчину в дозі 2 г/кг маси тіла щура. Виводили тварин з експерименту за умов знеболювання тіопентал-натрієм. Обстежено 60 статевозрілих самок білих щурів, яких поділили на 4 групи: до 1-ї групи ввійшли 20 самок, в яких після завершення експерименту досліджували біохімічні показники, оцінювали клінічні прояви гепатиту; до 2-ї - 20 самок, гепатит в яких лікували шляхом введення гепатопротекторного засобу (2,5 \% розчину тіотриазоліну по 0,1 мл підшкірно щоденно протягом 20 днів), аналогічні дослідження проводили після завершення лікування; до 3-ї 15 самок, в яких досліджували репродуктивну 
функцію; контрольну групу склали 5 здорових статевозрілих самок білих щурів. У піддослідних тварин визначали рівень загального білка, загального білірубіну, аланінамінотрансферази (АлАТ), аспартатамінотрансферази (АсАТ), лужної фосфатази (ЛФ), тимолової проби [1, 7, 9-11].

Статистичну обробку результатів виконано у відділі системних статистичних досліджень ДВНЗ “Тернопільський державний медичний університет імені І. Я. Горбачевського МОЗ України" в програмному пакеті Statsoft STATISTICA.

РЕЗУЛЬТАТИ Й ОБГОВОРЕННЯ. СерЕДніЙ вік самок білих щурів у дослідних групах склав від 6 до 8 місяців, у контрольній групі - 6 місяців. Маса піддослідних тварин в експериментальних та контрольній групах становила в середньому 190-195 г. Контрольна і всі дослідні групи були ідентичними за віком, масою, харчуванням, умовами утримування. У піддослідних тварин 1-3 груп було змодельовано тетрахлорметановий хронічний гепатит. Спостерігали за поведінкою щурів, їх руховою активністю, функцією травного тракту. Агресивну поведінку в перший тиждень експерименту відмічали у всіх піддослідних тварин. Наступного тижня спостерігали адинамію в 16 (80,0 \%) щурів 1-ї групи, 18 (90,0%) - 2-ї групи і 13 (86,7 \%) - 3-ї групи. Зниження апетиту відзначено у всіх тварин 1-3 груп. У третини щурів кожної експериментальної групи була відраза до їжі. Діарея мала місце в 17 (85,0 \%) самок 1-ї групи, 18 (90,0 \%) - 2-ї групи, 12 (80,0 \%) - 3-ї групи. В контрольній групі виконували аналогічні дослідження. Визначені показники підтверджували літературні дані [1, 2, 7, 9-11]. Через 3 місяці в 3-й дослідній групі проводили аналіз реалізації репродуктивної функції. Виявлено, що у 9 самок $(60,0 \%)$ вагітність не настала.

Під час біохімічних досліджень у тварин 1-ї групи одержано такі показники: загальний білірубін - $(20,99 \pm 0,41)$ мкмоль/л $(p<0,05)$; загальний білок - $(35,63 \pm 0,94)$ г/л $(p<0,05)$; АлАТ - (133,37 $\pm 2,36)$ Од/л $(p<0,05) ;$ АсАТ $(406,05 \pm 1,93)$ Од/л $(p<0,05) ;$ ЛФ $(941,79 \pm 19,36)$ Од/л $(p<0,05)$; тимолова проба - $(3,56 \pm 0,14)$ Од/л ( $<<0,05)$. У щурів 2-ї групи отримано такі результати: загальний білірубін $(4,58 \pm 0,20)$ мкмоль/л $(p<0,05)$; після лікування показники загального білка підвищились до $(71,69 \pm 1,88)$ г/л $(p<0,05)$; достовірно знизились АлАТ - $(77,64 \pm 2,36)$ Од/л і АсАТ $(260,89 \pm 5,83)$ Од/л $(p<0,05)$; рівень ЛФ досягнув $(383,96 \pm 13,01)$ Од/л $(p<0,05)$, тимолової проби - $(1,20 \pm 0,06)$ Од/л $(p<0,05)$ (табл.). Результати наших досліджень відповідають літературним даним [1, 2, 6, 7, 9-11].

Таблиця - Показники біохімічних досліджень при експериментальному токсичному гепатиті

\begin{tabular}{||l|c|c|c||}
\hline \multicolumn{1}{|c|}{ Показник } & $\begin{array}{c}\text { 1-ша експериментальна } \\
\text { група }(\mathrm{n}=20)\end{array}$ & $\begin{array}{c}2 \text {-га експериментальна } \\
\text { група }(\mathrm{n}=20)\end{array}$ & $\begin{array}{c}\text { Контрольна } \\
\text { група } \\
(\mathrm{n}=5)\end{array}$ \\
\cline { 2 - 4 } & без лікування & після лікування & $71,10 \pm 1,45$ \\
\hline Загальний білок, г/л & $35,63 \pm 0,94^{\star}$ & $71,69 \pm 1,88^{\star \star}$ & $4,04 \pm 0,01$ \\
\hline $\begin{array}{l}\text { Загальний білірубін, } \\
\text { мкмоль/л }\end{array}$ & $20,99 \pm 0,41^{\star}$ & $4,58 \pm 0,20^{\star \star}$ & $83,24 \pm 2,60$ \\
\hline АлАТ, Од/л & $133,37 \pm 2,36^{*}$ & $77,64 \pm 2,36^{\star \star}$ & $259,36 \pm 3,48$ \\
\hline АсАТ, Од/л & $406,05 \pm 1,93^{\star}$ & $260,89 \pm 5,83^{\star \star}$ & $400,20 \pm 10,62$ \\
\hline ЛФ, Од/л & $941,79 \pm 19,36^{\star}$ & $383,96 \pm 13,01^{\star \star}$ & $1,42 \pm 0,06$ \\
\hline Тимолова проба, Од/л & $3,56 \pm 0,14^{*}$ & $1,20 \pm 0,06^{\star \star}$ & \\
\hline
\end{tabular}

Примітка. * - достовірність порівняння з показниками без лікування ( $<<0,05)$; ** - достовірність порівняння 3 показниками після лікування $(\mathrm{p}<0,05)$.

ВИСНОВКИ. 1. При експериментальному токсичному гепатиті відбувається достовірне підвищення рівня трансаміназ.

2. За умов експериментального токсичного гепатиту спостерігають зниження рівня білка в крові у 2 рази.

3. Застосування метаболічної та гепатопротекторної терапії при експериментальному токсичному гепатиті призводить до поліпшення загального стану піддослідних тварин та достовірно покращує показники функції печінки.
4. У 60,0 \% самок білих щурів за умов експериментального токсичного гепатиту порушується репродуктивна функція.

Перспективи подальших досліджень. Заплановано продовжити дослідження ланок патогенезу порушень функції репродуктивної системи з метою оптимізації їх лікування, а також проблем реалізації репродуктивної функції. 


\section{СПИСОК ЛІТЕРАТУРИ}

1. Вивчення ліпотропної дії поліфенольних екстрактів з насіння винограду на моделі гострого тетрахлорметанового гепатиту / А. Л. Загайко, С. В. Заїка, О. А. Красільнікова, І. В. Сенюк // Укр. біофармац. журн. - 2012. - № 1-2 (18-19). C. 46-49.

2. Голубєва М. Г. Лікувальний вплив амізону на перебіг експериментального алкогольно-тетрахлорметанового гепатиту / М. Г. Голубєва // Ліки. 2003. - № 5-6. - С. 71-73.

3. Дубоссарская 3. М. Теория и практика гинекологической эндокринологии / З. М. Дубоссарская. Днепропетровск, 2005. - 409 с.

4. Загальні етичні принципи експериментів на тваринах // Перший національний конгрес з біоетики, Київ, 2001 р. // Ендокринологія. - 2003. - 8, № 1. - С. 142-145.

5. Концепція державної цільової соціальної програми профілактики, діагностики та лікування вірусних гепатитів на період до 2016 року МОЗ України [Електронний ресурс]. - Режим доступу : http:http:/aiddu.org.ua/wp-content/uploads/2014/10/ unifikovaniy-protokol-gepatiti-2014.pdf.

6. Короленко Т. А. Субклеточное распределение кислых гидролаз печени крыс при токсическом ге- патите / Т. А. Короленко, А. Е. Кондрикова, В. Г. Титова // Бюл. эксперим. биол. и мед. - 1975. - 80, № 7. - С. 35-36.

7. Рикало Н. А. Експериментальна модель хронічного тетрахлорметанового гепатиту та цирозу печінки у нестатевозрілих щурів / Н. А. Рикало // Вісн. Укр. мед. стомат. акад. - 2009. - 9, № 2. C. $116-118$.

8. Швец Н. И. Лекарственные поражения печени, связанные с приемом антибиотиков / Н. И. Швец, Т. М. Бенца // Суч. гастроентерол. - 2009. - № 3. C. 43-49.

9. Bhadauria M. Multiple treatment of propolis extract ameliorates carbon tetrachloride induced liver injury in rats / M. Bhadauria, S. K. Nirala, S. Shukla // Food Chem. Toxicol. - 2008. - 46 (8). P. 2703-2712.

10. Neoptolemos J. P. Fast fact: Diseases of the pancreas and biliary tract / J. P. Neoptolemos, M. S. Bhutani. - Oxford: Health Press, 2006. P. 112-117.

11. Protective effects of caffeic acid phenethyl ester (CAPE) on carbon tetrachloride-induced hepatotoxicity in rats / I. Kus, N. Colakoglu, H. Pekemez // Acta Histochem. - 2004. - 106 (4). - P. 289-297.

\section{ОСОБЕННОСТИ ФЕРМЕНТАТИВНОЙ И БЕЛКОВООБРАЗОВАТЕЛЬНОЙ ФУНКЦИЙ ПЕЧЕНИ ПРИ ЭКСПЕРИМЕНТАЛЬНОМ ХРОНИЧЕСКОМ ТОКСИЧЕСКОМ ГЕПАТИТЕ У ПОЛОВОЗРЕЛЫХ САМОК БЕЛЫХ КРЫС И ИХ ВЛИЯНИЕ НА РЕПРОДУКЦИЮ}

\section{Резюме}

Проблема нарушений функции репродуктивной системы занимает одно из ведущих мест среди гинекологических заболеваний и продолжает быть актуальной, так как приводит к потере трудоспособности и снижению репродуктивной функции. Значительная роль в этом принадлежит не только генетически детерминированным особенностям организма, но и сопутствующей патологии. У женщин часто наблюдают сочетание нарушений функции репродуктивной системы с хроническими гепатитами различного генеза. Это побудило нас к проведению экспериментальной работы с целью детального изучения и анализа указанной проблемы. Было смоделировано хронический токсический гепатит у половозрелых самок белых крыс. Изучено результаты клинических, гистологических исследований, показатели иммунного и гормонального статуса, состояние ферментативной и белковообразовательной функций печени у подопытных животных, а также их репродуктивную функцию в условиях экспериментального токсического гепатита. Обследовано 60 половозрелых самок белых крыс, у которых смоделировано хронический токсический гепатит. Исследовано клинические проявления заболевания, состояние ферментативной, белковообразовательной функций печени и репродуктивную функцию этих животных.

КЛЮЧЕВЫЕ СЛОВА: ферментативная и белковообразовательная функции печени, хронический токсический гепатит, репродуктивная функция. 


\section{FEATURES OF ENZYMATIC AND PROTEIN- SYNTHESIZING FUNCTION OF THE LIVER IN EXPERIMENTAL CHRONIC TOXIC HEPATITIS IN MATURE FEMALE OF WHITE RATS AND THEIR IMPACT ON REPRODUCTION}

\section{Summary}

The problem of functional disorders of the reproductive system is one of the leading places among gynecological diseases and continues to be relevant because not only leads to disability, but also to reduce the implementation of reproductive function. A significant role in this belongs not only genetically determined characteristics of the organism, but comorbidity. In women of reproductive age often there is a combination of the reproductive system dysfunction with chronic hepatitis of different genesis. This prompted us to conduct experimental work to detailed study and analysis of this problem. We simulated chronic toxic hepatitis in mature female rats. We studied the results of clinical, histological studies, indicators of immune and hormonal status, condition of enzymatic and protein- synthesizing liver function in experimental animals and their reproductive function in experimental toxic hepatitis. The study involved 60 sexually mature female rats, which simulated chronic toxic hepatitis. The clinical manifestations of the disease, condition of enzymatic and protein- synthesizing liver function and reproductive function of animals were investigated.

KEY WORDS: enzymatic and protein- synthesizing liver function, chronic toxic hepatitis, reproductive function.

Отримано 16.01.15

Адреса для листування: Л. Є. Лимар, Тернопільський державний медичний університет імені І. Я. Горбачевського, м. Волі, 1, Тернопіль, 46001, Україна. 